\title{
Herbicide Selectivity in Peanut Cultivars
}

\author{
Henrique Gonzalez Zanardo ${ }^{1}$, Willians César Carrega ${ }^{1}$, Neriane Hijano ${ }^{1}$, Anne Elise Cesarin ${ }^{1}$, \\ Pedro de F. R. Barbosa Martins ${ }^{1}$, Ignácio José de Godoy ${ }^{2} \&$ Pedro Luis da C. A. Alves ${ }^{1}$ \\ ${ }^{1}$ Weed Sciences Laboratory, Sao Paulo State University, Jaboticabal, SP, Brazil \\ ${ }^{2}$ Grain and Fiber Center, Agronomic Institute of Campinas, Campinas, SP, Brazil \\ Correspondence: Willians César Carrega, Weed Sciences Laboratory, University of Sao Paulo, Via de Acesso \\ Prof. Paulo Donato Castellane s/n, 14884-900, Jaboticabal, São Paulo, Brazil. Tel: 55-(17)-3209-7100/7732. \\ E-mail: willianscesar@hotmail.com
}

\author{
Received: May 6, $2018 \quad$ Accepted: June 9, $2018 \quad$ Online Published: July 15, 2018 \\ doi:10.5539/jas.v10n8p447 URL: https://doi.org/10.5539/jas.v10n8p447
}

\begin{abstract}
Weed interference is one of the main factors responsible for reducing the productivity of the peanut crop. Among weed control methods, the chemical is considered one of the main tools, however, the herbicides registered for this crop are scarce. The objective of this study was to evaluate the selectivity of herbicides applied in post-emergence in Runner peanut cultivars. For this, an experiment was performed in an 11x5 factorial scheme, meaning 10 herbicides plus one control (without herbicide) and five peanut cultivars, with four replicates. Visual evaluations of phytointoxication were carried out at 7, 14 and 21 days after application of the herbicides. At the end of the experiment, was determined the dry mass of aboveground and root parts. Based on the results obtained, it is concluded that the herbicides 2,4-D $\left(1.50 \mathrm{~L} \mathrm{ha}^{-1}\right)$, mesotrione $\left(0.3 \mathrm{~L} \mathrm{ha}^{-1}\right)$, saflufenacil $\left(0.75 \mathrm{~L} \mathrm{ha}^{-1}\right)$ imazapic $\left(175 \mathrm{~g} \mathrm{ha}^{-1}\right)$ and S-metolachlor $\left(1.75 \mathrm{~L} \mathrm{ha}^{-1}\right)$ have potential to be used for all the peanut cultivars studied. Herbicides hexazinone (2.50 kg ha-1), amicarbazone $\left(2.00 \mathrm{~kg} \mathrm{ha}^{-1}\right)$, tebuthiuron $\left(2.00 \mathrm{~L} \mathrm{ha}^{-1}\right)$, clomazone $\left(2.00 \mathrm{~L} \mathrm{ha}^{-1}\right)$ and sulfentrazone $\left(1.20 \mathrm{~L} \mathrm{ha}^{-1}\right)$ must not be indicated, at these doses, for post-emergence spraying in the evaluated cultivars. The genotypes do not react equally to certain products, therefore, there is a need for further studies the at field conditions to attest the responses obtained in the present study and verify that the yield potential is not affected.
\end{abstract}

Keywords: Arachis hypogaea L., intoxication, weeds, herbicides

\section{Introduction}

Peanuts (Arachis hypogea L.) are among the most important leguminous plants in the world, spotlighted as the fourth greatest oleaginous crop (Santos, Freire, \& Lima, 2013). Its productivity worldwide has surpassed the 44.6 million tons (USDA, 2018). In Brazil, the production is about 510 thousand tons and is concentrated on the state of São Paulo, which has more than $90 \%$ of the national production (CONAB, 2018).

Among the factors that may compromise the productive potential of the crop, the interference of weeds on the peanut plants is one of the most important. Weeds compete for environmental resources, such as water, light, nutrients and space (Pitelli, 1985). Competition causes direct losses on the crop, reducing qualitatively and quantitatively the productivity, raising the operational costs of harvesting and prejudicing the grain drying (Nepomuceno, Alves, Dias, Cardozo, \& Pavani, 2007). Some authors emphasized that weed infestation in peanut crops may cause reductions varying from 31 to $92 \%$ (Nepomuceno et al., 2007; Agostinho, Gravena, Alves, Salgado, \& Mattos, 2006; Yamauti, Alves, Nepomuceno, \& Martins, 2010), and this interference grade is dependent on cultivar, spacing, density and coexistence period, which may be modified by climate conditions and the cultural traits used (Pitelli, 1985).

Nowadays, on peanut crops, chemical control is the main method used to reduce the infestation of weeds. For Alvino et al. (2011), this method shows higher advantages for being more economical and efficient for control, especially in extensive crop areas with high infestation levels.

To avoid weed interference in peanut crops, after plant emergence it is common to perform a post-emergence herbicide application. However, one of the pre-requisites for herbicide use in this modality is the plant selectivity for the crop species (Oliveira Jr. \& Inoue, 2011). The selectivity is related to the fast metabolizing of the product, 
forming non-phytotoxical compounds (Martins et al., 2007). Nevertheless, depending on the dose used, method of application and environmental conditions, some herbicides may still cause some intoxication to the crop.

For peanut crops in Brazil, there are few selective herbicides registered on the Ministry of Agriculture, Livestock and Supply destined to control weeds in pre and post-emergence. Among those are alachlor (inhibitor of cell division), imazapic (inhibitor of ALS), pendimethalin (inhibitor of microtubule assembly), quizalofop-p-ethyl (ACCase inhibitor) and trifluralin (inhibitor of microtubule assembly). From these ingredients, only imazapic and quizalofop-p-ethyl recommended as post-emergence herbicides (Rodrigues \& Almeida, 2011).

Along with the low availability of products and the repetitive use of herbicides with the same active ingredient, there is the appearance of resistant weed species in crop areas. Worldwide, there are more than a thousand known cases of resistant weeds to herbicides. In Brazil, there are 43 reports of weeds resistant to one or more mechanisms of action (Heap, 2017). In peanuts, reports of herbicide resistant weeds were only found in USA with the discovery of Amaranthus palmeri and Ambrosia artemisiifolia (inhibitors of ALS enzyme). A. palmeri, if not controlled, may quickly dominate the crop and a single plant per linear meter may cause losses equivalent to $28 \%$ of the crop yield (Burke, Schroeder, Thomas, \& Wilcut, 2007).

In Brazil, there are no reports of resistant weeds in peanut crops, but in 2015 there was a report on this species $(A$. palmeri) in cotton crops, resisting EPSPs enzyme inhibitor herbicides and in 2016, in soybean and bean crops (same family of peanuts) and in cotton crops with multiple resistance (to ALS and EPSPs enzyme synthesis inhibitors) (Heap, 2017). In this way, it is necessary to broad the availability of products for crop management. One of the alternatives is through the usage of herbicides registered for other crops and that are not registered yet for peanuts. However, in Brazil, the use of these products was not permitted due political restraints. Recently, the peanut crop was included in MAPA as a Crop with Insufficient Phytosanitary Support (MAPA, 2015), enabling the opening of the portfolio of other crops to be used in peanuts.

As every peanut production comes from many areas of sugarcane renewal fields (CONAB, 2017), the use of herbicides also used in sugarcane may be a viable alternative. Amongst herbicides used in sugarcane are featured: 2,4-D (auxin mimetizers), sulfentrazone (inhibitors of Protoporphyinogen oxidase-PROTOX), hexazinone (inhibitor of photosystem II), clomazone (isoprenoid compounds biosynthesis inhibitor), mesotrione (carotenoid biosynthesis inhibitor), tebuthiuron (photosystem II inhibitor), imazapic (inhibitor of Acetolactate synthase-ALS), S-metolachlor (inhibitor of cell division) and amicarbazone (photosystem II inhibitor).

Besides, in face of the great availability of herbicides in sugarcane areas and considering peanut as the main crop in sugarcane renewal areas, the search for selective herbicides is of high importance. In this way, the present study had, as objective, to evaluate the selectivity of herbicides applied in post-emergence in peanut crop cultivars.

\section{Material and Methods}

\subsection{Experimental Area, Plant Materials, Treatments and Experimental Design}

The research was conducted in January, 2015, in the municipality of Jaboticabal, SP, located at $21^{\circ} 14^{\prime} 05^{\prime \prime} \mathrm{S}$ latitude and $48^{\circ} 17^{\prime} 09^{\prime \prime} \mathrm{W}$ longitude, at $615 \mathrm{~m}$ altitude, and it has a subtropical climate, with dry winters and rainy summers (Cwa), as stated in Köppen's climate classification.

The experiment was developed under semi-controlled conditions, without water restriction. The experimental design was in random blocks, in a factorial scheme of $11 \times 5$, having as treatments ten herbicides in post-emergence and a control plot (without chemical treatment) and five peanut cultivars, in four replications. The chemical treatments are presented in Table 1 and the dosages were the usually used in sugarcane. 
Table 1. Description of herbicides and doses used in the experiment in post-emergence

\begin{tabular}{|c|c|c|c|c|}
\hline Treatments & Active Ingredient & Commercial name & Doses (c.p. ha ${ }^{-1}$ ) & Doses $\left(\mathrm{kg} \mathrm{ha}^{-1}\right)$ \\
\hline 1 & $2,4-\mathrm{D}$ & Aminol $^{(\mathbb{R}}$ & $1.50 \mathrm{~L} \mathrm{ha}^{-1}$ & 1.209 a.e...ha ${ }^{-1}$ \\
\hline 2 & Sulfentrazone & Boral $^{\circledR}$ & $1.20 \mathrm{~L} \mathrm{ha}^{-1}$ & 0.600 a.i.ha ${ }^{-1}$ \\
\hline 3 & Hexazinone & Broker $^{\circledR}$ & $2.50 \mathrm{~kg} \mathrm{ha}^{-1}$ & 1.875 a.i.ha ${ }^{-1}$ \\
\hline 4 & Clomazone & Gamit $^{\circledR}$ & $2.00 \mathrm{~L} \mathrm{ha}^{-1}$ & 0.720 a.i.ha ${ }^{-1}$ \\
\hline 5 & Mesotrione & Callisto $^{\circledR}$ & $0.30 \mathrm{~L} \mathrm{ha}^{-1}$ & 0.144 a.i.ha ${ }^{-1}$ \\
\hline 6 & Saflufenacil & Heat $^{\circledR}$ & $0.75 \mathrm{~g} \mathrm{ha}^{-1}$ & 0.525 a.i.ha ${ }^{-1}$ \\
\hline 7 & Tebuthiuron & Combine $^{\circledR}$ & $2.00 \mathrm{~L} \mathrm{ha}^{-1}$ & 1.000 a.i.ha ${ }^{-1}$ \\
\hline 8 & Imazapic & Plateau $^{(}$ & $175 \mathrm{~g} \mathrm{ha}^{-1}$ & 0.122 a.i.ha ${ }^{-1}$ \\
\hline 9 & S-metolachlor & Dual-Gold $^{\circledR}$ & $1.75 \mathrm{~L} \mathrm{ha}^{-1}$ & 1.680 a.i.ha ${ }^{-1}$ \\
\hline 10 & Amicarbazone & Dinamic $^{\circledR}$ & $2.0 \mathrm{~kg} \mathrm{ha}^{-1}$ & 1.400 a.i.ha ${ }^{-1}$ \\
\hline 11 & \multicolumn{4}{|c|}{ Control plot (No herbicide application) } \\
\hline
\end{tabular}

Seeds of the genotypes (four cultivars and a breeding line) were disposed by the Instituto Agronômico de Campinas (IAC). The sowing was performed in vases of $2.5 \mathrm{~L}$ volumetric capacity, filled with a substratum composed of a mixture of soil and sand $(2: 1 \mathrm{v} / \mathrm{v})$. The soil used was classified as an Oxisol, red and distrofic, mean texture (Embrapa, 2013), with chemical analysis results as described in Table 2.

Table 2. Results from chemical analysis of the substratum used

\begin{tabular}{|c|c|c|c|c|c|c|c|c|c|}
\hline & & & & & & $\mathrm{H}+\mathrm{Al}$ & Sum of Bases & & Sat. \\
\hline $\mathrm{pH}$ & O.M. & P. (resin) & $\mathrm{K}$ & $\mathrm{Ca}$ & $\mathrm{Mg}$ & SMP & S.B. & $\mathrm{T}$ & Bases \\
\hline $\mathrm{CaCl}_{2}$ & $\mathrm{~g} \mathrm{dm}^{-3}$ & $--\mathrm{mg} \mathrm{dm}^{-3}--$ & --- & ----- & ----- & --- mmo & $n^{-3}-$ & -------- & $\mathrm{V} \%$ \\
\hline 5.6 & 13 & 34 & 1.8 & 24 & 6 & 15 & 31.8 & 46.8 & 68 \\
\hline
\end{tabular}

In each vase a cultivar was sown (IAC Tatu-ST, Line 870, IAC 505, IAC 503 and Granoleico), depositing 15 seed at $3 \mathrm{~cm}$ depth. Seeds were previously treated with insecticide tiametoxam and fungicide carboxine + thiram to avoid interference with insects and pathogens. After 7 days of plant emergence, the plant thinning was performed, leaving only two plants per plot. As a preventive treatment to the action of insects and diseases, at 35 days after sowing (DAS) and weekly during the experimental period, the insecticide tiametoxam $\left(200 \mathrm{~mL} \mathrm{ha}^{-1}\right)$ and fungicide piraclostrobine $\left(600 \mathrm{~mL} \mathrm{ha}^{-1}\right)$ were applied.

\subsection{Herbicide Application}

Herbicide spraying was performed at 30 DAS with a costal sprayer with constant pressure $\left(\mathrm{CO}_{2}\right)$ equipped with a four sprayers, TTJ60-11002 VP nozzle, spaced in $0.5 \mathrm{~m}$. The equipment was regulated at constant pressure of 2.2 bar to distribute $200 \mathrm{~L} \mathrm{ha}^{-1}$ mixture volume. At spraying time, data of temperature $\left(33^{\circ} \mathrm{C}\right)$ and relative humidity (68\%) were registered.

\subsection{Assessed Variables and Statistical Analysis}

Visual evaluations of phytotoxicity were made at 7, 14 and 21 days after application (DAA) in post-emergence using the scale proposed by EWRC (1964). At the end of the experiment (21 DAA), dry matter of aboveground and root parts were determined, obtained through drying in air-circulation oven at $65{ }^{\circ} \mathrm{C}$ for 76 hours, until constant mass.

Data obtained was submitted to analysis of variance through $\mathrm{F}$ test and means compared by Tukey test $(\mathrm{p}<$ 0.05).

\section{Results}

Analyzing the interaction between herbicides for each cultivar, at 7 DAA, it was observed that, for IAC Tatu-ST, hexazinone and amicarbazone caused the highest levels of phytointoxication when compared to the control plot (Table 3). At 14 DAA, this cultivar showed more susceptible to hexazinone, amicarbazone and tebuthiuron; the first two were considered the causers of plant death in this date. Still at 14 DAA, a strong phytointoxication was observed in plants submitted to applications of sulfentrazone and clomazone (Table 4). In the evaluation at 21 DAA, it was verified similar effect as verified at 14 DAA, but tebuthiuron also provoked the death of the plants 
(Table 5). For Line 870, the products that caused most phytointoxications were hexazinone, clomazone, amicarbazone and tebuthiuron when compared to the control plot at 7 DAA (Table 3). At 14 DAA, three products (hexazinone, clomazone and amicarbazone) showed to be the cause of the death of plants and those treated with tebuthiuron showed increase of intoxication, reaching very strong level (Table 4). At 21 DAA, it was observed that the use of these products caused the death of this cultivar (Table 5).

Table 3. Split analysis of interaction between cultivars and products for the evaluation of phytointoxication at 7 DAA

\begin{tabular}{|c|c|c|c|c|c|c|}
\hline \multirow{2}{*}{ Treatments } & \multicolumn{5}{|c|}{ Genotypes } & \multirow{2}{*}{$\mathrm{F}$} \\
\hline & IAC Tatu-ST & Line 870 & IAC 505 & IAC 503 & Granoleico & \\
\hline $2,4-\mathrm{D}$ & $2.50 \mathrm{DEFa}$ & 2.50CDEa & $1.25 \mathrm{DEa}$ & $1.75 \mathrm{BCDa}$ & $2.25 \mathrm{DEa}$ & $2.38^{\mathrm{ns}}$ \\
\hline Sulfentrazone & $4.50 \mathrm{BCa}$ & $3.75 \mathrm{BCab}$ & $4.00 \mathrm{ABab}$ & $3.00 \mathrm{ABCb}$ & 4.25 BCab & $2.68 *$ \\
\hline Hexazinone & $6.50 \mathrm{Aa}$ & $6.25 \mathrm{Aab}$ & $5.00 \mathrm{Abc}$ & $4.50 \mathrm{Ac}$ & $6.25 \mathrm{Aab}$ & $6.42 * *$ \\
\hline Clomazone & $3.25 \mathrm{CDEb}$ & $6.25 \mathrm{Aa}$ & $3.50 \mathrm{ABCb}$ & $4.00 \mathrm{Ab}$ & $3.50 \mathrm{CDb}$ & $12.29 * *$ \\
\hline Mesotrione & $1.75 \mathrm{EFab}$ & $1.50 \mathrm{DEb}$ & 2.00 CDEab & $1.25 \mathrm{Db}$ & $3.00 \mathrm{CDa}$ & $3.69 * *$ \\
\hline Saflufenacil & $2.75 \mathrm{DEa}$ & $2.75 \mathrm{CDa}$ & $2.75 \mathrm{BCDa}$ & $2.25 \mathrm{BCDa}$ & $3.25 \mathrm{CDa}$ & $1.01^{\mathrm{ns}}$ \\
\hline Tebuthiuron & 3.75 BCDbc & $5.25 \mathrm{ABa}$ & $2.75 \mathrm{BCDc}$ & $4.25 \mathrm{Aab}$ & $5.50 \mathrm{ABa}$ & $10.21 * *$ \\
\hline Imazapic & $1.00 \mathrm{Fb}$ & 2.50 CDEa & 1.25DEab & 1.50 CDab & 1.25 Eab & $2.78^{*}$ \\
\hline S-metolachlor & $1.75 \mathrm{EFa}$ & $2.00 \mathrm{DEa}$ & $1.00 \mathrm{Ea}$ & $1.25 \mathrm{Da}$ & $1.25 \mathrm{Ea}$ & $1.37^{\mathrm{ns}}$ \\
\hline Amicarbazone & $5.00 \mathrm{ABa}$ & $5.75 \mathrm{Aa}$ & $5.00 \mathrm{Aa}$ & $3.25 \mathrm{ABb}$ & $3.50 \mathrm{CDb}$ & $9.36^{* *}$ \\
\hline Control & $1.00 \mathrm{Fa}$ & $1.00 \mathrm{Ea}$ & $1.00 \mathrm{Ea}$ & $1.00 \mathrm{Da}$ & $1.00 \mathrm{Ea}$ & $0.00^{\mathrm{ns}}$ \\
\hline $\mathrm{F}$ & $24,69 * *$ & $30,97 * *$ & $18,92 * *$ & $13,84^{* *}$ & $23,67 * *$ & - \\
\hline
\end{tabular}

Note. Means followed by same upper case letter on columns and lower case letters in lines do not differ at $5 \%$ probability level by Tukey test. By $\mathrm{F}$ test, $* *$ : significant at $1 \%$, and *: significant at $5 \%$ probability, ${ }^{\text {ns }}$ : non significant. $\mathrm{F}(\mathrm{A} \times \mathrm{B})=3.67 ; \mathrm{CV}(\%)=23.33$.

Table 4. Split analysis of interaction between cultivars and products for the evaluation of phytointoxication at 14 DAA

\begin{tabular}{lllllll}
\hline \multirow{2}{*}{ Treatments } & \multicolumn{5}{c}{ Genotypes } \\
\cline { 2 - 6 } & IAC Tatu-ST & Line 870 & IAC 505 & IAC 503 & Granoleico \\
\hline Sulfentrazone & $2.00 \mathrm{CDa}$ & $3.00 \mathrm{Ca}$ & $1.75 \mathrm{DEa}$ & $2.00 \mathrm{EFa}$ & $2.25 \mathrm{DEFa}$ & $1.54^{\mathrm{ns}}$ \\
Hexazinone & $7.25 \mathrm{Aba}$ & $5.00 \mathrm{Bb}$ & $3.75 \mathrm{BCb}$ & $4.00 \mathrm{CDb}$ & $4.50 \mathrm{BCb}$ & $13.01^{* *}$ \\
Clomazone & $9.00 \mathrm{Aa}$ & $9.00 \mathrm{Aa}$ & $9.00 \mathrm{Aa}$ & $8.50 \mathrm{Aa}$ & $9.00 \mathrm{Aa}$ & $0.33^{\mathrm{ns}}$ \\
Mesotrione & $2.75 \mathrm{CDa}$ & $2.00 \mathrm{CDa}$ & $2.50 \mathrm{CDEa}$ & $2.25 \mathrm{DEFa}$ & $3.00 \mathrm{CDEa}$ & $1.04^{\mathrm{ns}}$ \\
Saflufenacil & $3.25 \mathrm{Ca}$ & $2.50 \mathrm{CDa}$ & $3.50 \mathrm{BCDa}$ & $3.75 \mathrm{CDEa}$ & $4.00 \mathrm{BCDa}$ & $2.20^{\mathrm{ns}}$ \\
Tebuthiuron & $8.50 \mathrm{Aa}$ & $8.25 \mathrm{Aa}$ & $7.75 \mathrm{Aa}$ & $8.25 \mathrm{Aa}$ & $8.50 \mathrm{Aa}$ & $1.37^{\mathrm{ns}}$ \\
Imazapic & $2.25 \mathrm{CDb}$ & $5.00 \mathrm{Ba}$ & $2.00 \mathrm{CDEb}$ & $2.00 \mathrm{EFb}$ & $2.25 \mathrm{DEFb}$ & $11.10^{* *}$ \\
S-metolachlor & $3.00 \mathrm{Cb}$ & $3.50 \mathrm{BCb}$ & $2.25 \mathrm{CDEb}$ & $5.50 \mathrm{BCa}$ & $2.00 \mathrm{EFb}$ & $12.89^{* *}$ \\
Amicarbazone & $9.00 \mathrm{Aa}$ & $9.00 \mathrm{Aa}$ & $9.00 \mathrm{Aa}$ & $8.75 \mathrm{Aa}$ & $8.75 \mathrm{Aa}$ & $0.12^{\mathrm{ns}}$ \\
Control & $1.00 \mathrm{Da}$ & $1.00 \mathrm{Da}$ & $1.00 \mathrm{Ea}$ & $1.00 \mathrm{Fa}$ & $1.00 \mathrm{Fa}$ & $0.00^{\mathrm{ns}}$ \\
$-\mathrm{F}$ & $63.14^{* *}$ & $66.98^{* *}$ & $58.57^{* *}$ & $56.47^{* *}$ & $57.41^{* *}$ & - \\
\hline
\end{tabular}

Note. Means followed by same upper case letter on columns and lower case letters in lines do not differ at $5 \%$ probability level by Tukey test. By $\mathrm{F}$ test, **: significant at $1 \%$, and *: significant at $5 \%$ probability, ${ }^{\text {ns. }}$ : non significant. $\mathrm{F}(\mathrm{A} \times \mathrm{B})=5.03 ; \mathrm{CV}(\%)=16.18$. 
Table 5. Split analysis of interaction between cultivars and products for the evaluation of phytointoxication at 21 DAA

\begin{tabular}{|c|c|c|c|c|c|c|}
\hline \multirow{2}{*}{ Treatments } & \multicolumn{5}{|c|}{ Genotypes } & \multirow{2}{*}{$\mathrm{F}$} \\
\hline & IAC Tatu-ST & Line 870 & IAC 505 & IAC 503 & Granoleico & \\
\hline $2,4-\mathrm{D}$ & $2.50 \mathrm{CDa}$ & $3.00 \mathrm{Ca}$ & $3.00 \mathrm{CDa}$ & $2.00 \mathrm{DEa}$ & $2.75 \mathrm{CDEa}$ & $1.06^{\mathrm{ns}}$ \\
\hline Sulfentrazone & $7.25 \mathrm{Aba}$ & $5.75 \mathrm{Bab}$ & $4.50 \mathrm{BCb}$ & $4.25 \mathrm{BCb}$ & $4.50 \mathrm{BCb}$ & $9.70 * *$ \\
\hline Hexazinone & $9.00 \mathrm{Aa}$ & $9.00 \mathrm{Aa}$ & $9.00 \mathrm{Aa}$ & $9.00 \mathrm{Aa}$ & $9.00 \mathrm{Aa}$ & $0.00^{\mathrm{ns}}$ \\
\hline Clomazone & $6.00 \mathrm{Bc}$ & $9.00 \mathrm{Aa}$ & $6.25 \mathrm{Bbc}$ & 7.75Aab & $6.25 \mathrm{Bbc}$ & $10.15 * *$ \\
\hline Mesotrione & $2.50 \mathrm{CDa}$ & $2.75 \mathrm{CDa}$ & $2.50 \mathrm{DEa}$ & $1.75 \mathrm{DEa}$ & $3.00 \mathrm{CDa}$ & $1.33^{\mathrm{ns}}$ \\
\hline Saflufenacil & $3.25 \mathrm{Ca}$ & $3.25 \mathrm{Ca}$ & $3.50 \mathrm{CDa}$ & $3.50 \mathrm{CDa}$ & $4.00 \mathrm{CDa}$ & $0.57^{\mathrm{ns}}$ \\
\hline Tebuthiuron & $9.00 \mathrm{Aa}$ & $9.00 \mathrm{Aa}$ & $8.25 \mathrm{Aa}$ & $8.75 \mathrm{Aa}$ & $9.00 \mathrm{Aa}$ & $0.65^{\mathrm{ns}}$ \\
\hline Imazapic & $2.25 \mathrm{CDb}$ & $6.25 \mathrm{Ba}$ & $3.50 \mathrm{CDb}$ & $2.25 \mathrm{DEb}$ & $2.50 \mathrm{DEb}$ & $17.60 * *$ \\
\hline S-metolachlor & $2.75 \mathrm{CDb}$ & $4.50 \mathrm{BCa}$ & 2.50 DEb & $5.75 \mathrm{Ba}$ & $2.25 \mathrm{DEb}$ & $13.95 * *$ \\
\hline Amicarbazone & $9.00 \mathrm{Aa}$ & $9.00 \mathrm{Aa}$ & $9.00 \mathrm{Aa}$ & $9.00 \mathrm{Aa}$ & $9.00 \mathrm{Aa}$ & $0.00^{\mathrm{ns}}$ \\
\hline Control & $1.00 \mathrm{Da}$ & $1.00 \mathrm{Da}$ & $1.00 \mathrm{Ea}$ & $1.00 \mathrm{Ea}$ & $1.00 \mathrm{Ea}$ & $0.00^{\mathrm{ns}}$ \\
\hline $\mathrm{F}$ & $59.74 * *$ & $54.36^{* *}$ & $49.27 * *$ & $60.90^{* *}$ & $54.38 * *$ & - \\
\hline
\end{tabular}

Note. Means followed by same upper case letter on columns and lower case letters in lines do not differ at $5 \%$ probability level by Tukey test. By $\mathrm{F}$ test, ${ }^{* *}$ : significant at $1 \%$, and $*$ : significant at $5 \%$ probability, ${ }^{\text {ns. }}$ non significant. $\mathrm{F}(\mathrm{A} \times \mathrm{B})=4.65 ; \mathrm{CV}(\%)=16.03$.

Cultivar IAC 505 was the most sensible to the application of hexazinona and amicarbazone at 7 DAA, with phytointoxication considered medium (Table 3). However, at 14 DAA, it was observed the increase of phytointoxication due to the use of hexazinone and amicarbazone, causing the death of plants; tebuthiuron caused strong intoxication when compared to the control plot (Table 4). At 21 DAA, besides the products that caused death of the plants, tebuthiuron cause very strong phytotoxical symptoms, affecting the development in those plants (Table 5).

Regarding cultivar IAC 503, at 7 DAA, it was observed that the products hexazinone, tebuthiuron and clomazone promoted higher phytointoxication, not different from sulfentrazone and amicarbazone (Table 3). At 14 DAA, it was verified that, besides these three products, the use of amicarbazone caused the increase of phytointoxication levels (Table 4). At the evaluation of 21 DAA, hexazinone and amicarbazone provoked death of plants, and tebuthiuron and clomazone caused sever intoxication (Table 5), compromising the development of the plants. It is important to note that, if there was another evaluation for these treatments after 21 DAA, these products would also have caused the plants to die.

For Granoleico, at 7 DAA (Table 3), hexazinone and tebuthiuron caused higher phytointoxication levels when compared to the control plot. At 14 DAA, it was observed that the use of hexazinone lead to the death of plants, while tebuthiuron and amicarbazone caused very strong intoxication levels in this cultivar (Table 4). In Table 5, it was observed that the three products (hexazinone, tenuthiuron and amicarbazone) caused the death of the plants.

Comparing the cultivars for each herbicide, at 7 DAA, it was verified that 2,4-D, saflufenacil and S-metolachlor did not cause any phytointoxication harm, not differing between the cultivars. For sulfentrazone and hexazinone, it was observed that IAC Tatu-ST was the most affected and IAC 503 was the least affected. Clomazone presented higher phytointoxication levels in Line 870 . Tebuthiuron caused more phytointoxication symptoms in Granoleico and in line 870 plants. The highest levels of phytointoxication caused by amicarbazone were in IAC Tatu-ST, IAC 505 and Line 870 (Table 3).

Analyzing the effect of each herbicide between cultivars in evaluations performed at 14 and 21 DAA, no difference was observed among cultivars when used 2,4-D, hexazinone, mesotrione, saflufenacil, tebuthiuron, amicarbazone, showing a similar behavior among genotypes. For sulfentrazone, it is stated that IAC Tatu-ST was the most susceptible, having a higher phytointoxication level when compared to the other cultivars. For clomazone, line 870 was the most sensible, followed by IAC 503, when compared to the remaining genotypes. Imazapic application caused more injuries to line 870. For S-metolachlor, it is observed that, among the genotypes, IAC 503 was the most harmed one from 14 DAA and line 870 was also most harmed from 21 DAA, showing the highest phytointoxication (Tables 4 and 5). 
Comparing herbicides for each cultivar and genotypes for each herbicide, it was observed that hexazinone, tebuthiuron and amicarbazone caused the death of plants in all genotypes, and so, there was no dry matter available for evaluation of aboveground and root parts.

For root dry matter content, it was verified that all products, with exception of 2,4-D, provoked a reduction in IAC Tatu-ST dry matter content. It was verified that some products reduced the root dry matter of IAC 505 and IAC 503 when compared to the control plot, except when S-metolachlor and mesotrione were applied (Table 6). For Line 870, it was verified that all products caused mass reduction when compared to the control plot. In Granoleico, besides the products that caused the death of plants, clomazone was the only one to cause root dry matter content reduction. Observing the split analysis of each herbicide among the cultivars, it was observed that 2,4-D and saflufenacil provoked a root reduction in all genotypes when compared to IAC Tatu-ST. Clomazone, imazapic and S-metolachlor showed higher reduction in Line 870, IAC 503 and Granoleico. Mesotrione provoked reduction in all genotypes when compared to IAC 503 (Table 6).

For aboveground dry matter content, it was observed that every product, except for 2,4-D caused reductions in IAC Tatu-St. For Line 870, every product provoked dry matter reduction, except for clomazone, when compared to the control plot. Analyzing IAC 505, the only treatments that did not cause dry matter reduction were mesotrione and S-metolachlor. For IAC 503, except for mesotrione the products applied caused dry matter reduction. In Granoleico, the products that did not cause aboveground mass reduction when compared to the control plot were 2,4-D, sulfentrazone, saflufenacil, imazapic and S-metolachlor. Comparing the effect of each herbicide among the genotypes, it is observed that 2,4-D caused reduction in every genotype when compared to IAC Tatu-ST. Analyzing sulfentrazone, mesotrione and S-metolachlor, it was observed that every genotype studied presented less mass when compared to Line 870. Saflufenacil and imazapic caused the dry matter reduction of IAC 503, Granoleico and Line 870 when compared to IAC Tatu-ST and IAC 505 (Table 7).

Table 6. Split analysis of interaction between cultivars and products for root mass of peanut genotypes submitted to different herbicide treatments in post-emergence at $21 \mathrm{DAA}$

\begin{tabular}{lllllll}
\hline \multirow{2}{*}{ Treatments } & \multicolumn{5}{c}{ Genotypes } \\
\cline { 2 - 7 } & IAC Tatu-ST & Line 870 & IAC 505 & IAC 503 & Granoleico \\
\hline S.4-D & $4.01 \mathrm{Aa}$ & $1.34 \mathrm{BCc}$ & $1.58 \mathrm{Dc}$ & $2.33 \mathrm{Bb}$ & $1.02 \mathrm{Abc}$ & $55.49^{* *}$ \\
Sulfentrazone & $1.99 \mathrm{Ca}$ & $1.04 \mathrm{BCb}$ & $1.94 \mathrm{CDa}$ & $2.35 \mathrm{Ba}$ & $1.31 \mathrm{Abc}$ & $11.15^{* *}$ \\
Hexazinone & $0.00 \mathrm{Da}$ & $0.00 \mathrm{Da}$ & $0.00 \mathrm{Ea}$ & $0.00 \mathrm{Ea}$ & $0.00 \mathrm{Ca}$ & $0.00^{\mathrm{ns}}$ \\
Clomazone & $1.86 \mathrm{Ca}$ & $0.84 \mathrm{Cbc}$ & $1.26 \mathrm{Dab}$ & $1.12 \mathrm{Dbc}$ & $0.59 \mathrm{BCc}$ & $8.94^{* *}$ \\
Mesotrione & $2.31 \mathrm{BCb}$ & $1.61 \mathrm{Bc}$ & $2.69 \mathrm{Bb}$ & $3.77 \mathrm{Aa}$ & $1.03 \mathrm{ABc}$ & $42.72^{* *}$ \\
Saflufenacil & $3.03 \mathrm{Ba}$ & $0.91 \mathrm{BCb}$ & $1.43 \mathrm{Db}$ & $1.49 \mathrm{CDb}$ & $0.98 \mathrm{ABb}$ & $28.61^{* *}$ \\
Tebuthiuron & $0.00 \mathrm{Da}$ & $0.00 \mathrm{Da}$ & $0.00 \mathrm{Ea}$ & $0.00 \mathrm{Ea}$ & $0.00 \mathrm{Ca}$ & $0.00^{\mathrm{ns}}$ \\
Imazapic & $3.02 \mathrm{Ba}$ & $0.85 \mathrm{Cd}$ & $2.66 \mathrm{BCab}$ & $2.37 \mathrm{Bb}$ & $1.53 \mathrm{Ac}$ & $30.32^{* *}$ \\
S-metolachlor & $2.87 \mathrm{Ba}$ & $1.25 \mathrm{BCb}$ & $3.27 \mathrm{Aba}$ & $1.23 \mathrm{Db}$ & $1.38 \mathrm{Ab}$ & $38.14^{* *}$ \\
Amicarbazone & $0.00 \mathrm{Da}$ & $0.00 \mathrm{Da}$ & $0.00 \mathrm{Ea}$ & $0.00 \mathrm{Ea}$ & $0.00 \mathrm{Ca}$ & $0.00^{\mathrm{ns}}$ \\
Control & $4.03 \mathrm{Aa}$ & $2.48 \mathrm{Ac}$ & $3.49 \mathrm{Aa}$ & $3.17 \mathrm{Ab}$ & $1.37 \mathrm{Ad}$ & $25.65^{* *}$ \\
F & $78.05^{* *}$ & $22.41^{* *}$ & $64.40^{* *}$ & $57.25^{* *}$ & $13.75^{* * *}$ & - \\
\hline
\end{tabular}

Note. Means followed by same upper case letter on columns and lower case letters in lines do not differ at $5 \%$ probability level by Tukey test. By $\mathrm{F}$ test, ${ }^{* *}$ : significant at $1 \%$, and $*$ : significant at $5 \%$ probability, ${ }^{\mathrm{ns}}$ : non significant. $\mathrm{F}(\mathrm{A} \times \mathrm{B})=12.90 ; \mathrm{CV}(\%)=22.97$. 
Table 7. Split analysis of interaction between cultivars and products for aboveground parts mass of peanut genotypes submitted to different herbicide treatments in post-emergence at 21 DAA

\begin{tabular}{lllllll}
\hline \multirow{2}{*}{ Treatments } & \multicolumn{5}{c}{ Genotypes } \\
\cline { 2 - 7 } & IAC Tatu-ST & Line 870 & IAC 505 & IAC 503 & Granoleico \\
\hline Sulfentrazone & $4.89 \mathrm{Aa}$ & $2.30 \mathrm{BCDb}$ & $2.46 \mathrm{Cb}$ & $2.39 \mathrm{BCb}$ & $2.34 \mathrm{Ab}$ & $40.68^{* *}$ \\
Hexazinone & $2.27 \mathrm{Ebc}$ & $2.02 \mathrm{CDc}$ & $4.02 \mathrm{Ba}$ & $2.95 \mathrm{Bb}$ & $2.42 \mathrm{Abc}$ & $20.13^{* *}$ \\
Clomazone & $0.00 \mathrm{Fa}$ & $0.00 \mathrm{Ea}$ & $0.00 \mathrm{Da}$ & $0.00 \mathrm{Ea}$ & $0.00 \mathrm{Da}$ & $0.00^{\text {ns }}$ \\
Mesotrione & $2.56 \mathrm{~Eb}$ & $4.00 \mathrm{Aa}$ & $2.41 \mathrm{Cb}$ & $1.94 \mathrm{CDbc}$ & $1.36 \mathrm{Cc}$ & $31.01^{* *}$ \\
Saflufenacil & $2.96 \mathrm{CDEc}$ & $1.94 \mathrm{CDd}$ & $5.17 \mathrm{Aa}$ & $3.77 \mathrm{Ab}$ & $1.46 \mathrm{BCd}$ & $70.32^{* *}$ \\
Tebuthiuron & $3.77 \mathrm{BCa}$ & $2.43 \mathrm{BCDb}$ & $3.16 \mathrm{Ca}$ & $1.48 \mathrm{Dc}$ & $1.97 \mathrm{ABCbc}$ & $26.91^{* *}$ \\
Imazapic & $0.00 \mathrm{Fa}$ & $0.00 \mathrm{Ea}$ & $0.00 \mathrm{Da}$ & $0.00 \mathrm{Ea}$ & $0.00 \mathrm{Da}$ & $0.00^{\text {ns }}$ \\
S-metolachlor & $3.58 \mathrm{BCDa}$ & $1.64 \mathrm{Dc}$ & $3.00 \mathrm{Cab}$ & $2.54 \mathrm{BCb}$ & $1.69 \mathrm{ABCc}$ & $22.45^{* *}$ \\
Amicarbazone & $2.90 \mathrm{DEb}$ & $2.59 \mathrm{BCbc}$ & $5.83 \mathrm{Aa}$ & $1.43 \mathrm{Dd}$ & $2.12 \mathrm{ABCc}$ & $91.61^{* *}$ \\
Control & $0.00 \mathrm{Fa}$ & $0.00 \mathrm{Ea}$ & $0.00 \mathrm{Da}$ & $0.00 \mathrm{Ea}$ & $0.00 \mathrm{Da}$ & $0.00^{\mathrm{ns}}$ \\
\hdashline F & $4.83 \mathrm{Aa}$ & $3.97 \mathrm{Ab}$ & $5.42 \mathrm{Aa}$ & $3.73 \mathrm{Ab}$ & $2.27 \mathrm{Abc}$ & $59.91^{* *}$ \\
\hline
\end{tabular}

Note. Means followed by same upper case letter on columns and lower case letters in lines do not differ at $5 \%$ probability level by Tukey test. By $\mathrm{F}$ test, ${ }^{* *}$ : significant at $1 \%$, and $*$ : significant at $5 \%$ probability, ${ }^{\mathrm{ns}}$ : non significant. $\mathrm{F}(\mathrm{A} \times \mathrm{B})=18.20 ; \mathrm{CV}(\%)=15.58$.

\section{Discussion}

Selectivity to herbicides is related to the plant absorption, translocation and metabolism, able to be different regarding species due physiological and morphological characteristics, being the cultivar selected one of the factors that may potentially affect the retention and absorption of herbicides by plants (Oliveira Jr. \& Inoue 2011).

Studies on the effects of the herbicides tested in this work are scarce for peanut crop. For 2,4-D, in the dosis used, it was verified low phytotoxicity levels for all five genotypes evaluated. Among the effects caused by the product, it could be observed epinasty and brown blots, which caused initial retardation in the initial development right after the application. However, this "paralyzation" was early and temporary, not affecting the growth and development of plants. Leon and Tillman (2015), applying 2,4-D in post-emergence in peanuts, also verified mild effects of phytointoxication. Some authors mention that there is direct relation between lesion caused by herbicides at early growth and losses in crop yield (Leon, Ferrell, \& Brecke, 2014; Prostko et al., 2013). However, Leon and Tillman (2015) mention that even with plant presenting lesions and reduction in dry matter after herbicide usage in the initial growth, it does not necessarily mean that peanut will show yield losses. Based on the present results observed here, peanut plants submitted to 2,4-D application show great recovery potential to the symptoms caused, being 3 the highest level attributed using EWRC (1964) scale at 21 DAA. Studies performed by Luvezuti, Bacha, Alves, Pavani, and Nepomuceno (2014) show that trifluralin mixed with 2,4-D provoked mild phytotoxicity levels, causing $40 \%$ intoxication at $21 \mathrm{DAA}$, but after that, there was complete recovery of cultivar Runner IAC 886 . These results show that the use of this product may be a viable alternative for post-emergence application. In other crops, such as pearl millet, the application of 2,4-D at 536 and $670 \mathrm{~g}$ a.i. ha $^{-1}$ dosage $\left(0.8\right.$ and $\left.1.0 \mathrm{~L} \mathrm{ha}^{-1}\right)$ resulted in an efficiency superior to $85 \%$, characterized as very good control of Raphanus raphanistrum L., without phytotoxic symptoms in the-plants (Farinelli, Penariol, \& Lemos, 2005). In soybeans (Fabaceae), Fleck, Neves, Vidal, and Vargas (1998), using 2,4-D in post-emergence, verified that morphological and reproductive variables were not affected by the product, thus presenting a good alternative for use in leguminous crops.

In Brazil, the application of sulfentrazone in pre and post-emergence is still not recommended and there is no registration of this herbicide for peanuts. In USA, in 2003, a sulfentrazone based product was registered with recommendation for pre-plant incorporated (PPI) and pre-emergence (CAES, 2003). Sulfentrazone is primarily absorbed by roots and control weeds through protoporphyinogen oxidase (membrane breaking). According to Thomas, Troxler, Smith, Fisher, and Wilcut (2005), studies performed previously indicate that the concentration of sulfentrazone in peanut roots diminishes along the time as it moves to aboveground parts. According to Grey, Dotray, and Grichar (2007), peanut is tolerant to this herbicide due to its metabolization capacity, but lesions as necrosis and growth reduction are observed. In this study, sulfentrazone application in post-emergence also 
caused injuries in peanut plants, similar to those reported by CAES (2003). For cultivars studied here, there was initial chlorosis, followed by leaf yellowing and posterior necrosis, which leads to leaf falling in cultivar IAC Tatu-ST (most susceptible cultivar) at the 7 DAA application. The remaining cultivars were less affected, but also showed chlorotic leaves and intermediary levels of phytointoxication.

The use of clomazone caused strong phytotoxicity levels for every evaluated cultivar; Line 870 was the most susceptible in 14 DAA and did not survive. Besides this genotype, cultivar IAC 503 also showed high susceptibility, but until 21 DAA, the plants did not die. Symptoms caused by clomazone were leaves completely chlorotic (white) with posterior death of the vegetal tissue and less growth and development. These symptoms are characteristic of isoprenoid compounds biosynthesis inhibitors. With this inhibition, there is no green pigment (chlorophyll) formation and the photosynthesis is inhibited, and, depending on phytotoxicity levels, may lead to plant death, as verified for Line 870 .

Mesotrione is a product recommended for maize and sugarcane in post-emergence (Rodrigues \& Almeida 2011). In maize, the use of mesotrione in post-emergence did not cause any injuries superior to 3\% (Armel, Wilson, Richardson, \& Hines, 2003). In peanut, there are no previous reports of its use in post-emergence. However, in this work, it was found that it caused mild phytotoxicity levels (leaves yellowing) until 21 DAA. For S-metolachlor, symptoms present were similar to those from mesotrione (leaves yellowing and brand phytotoxicity levels). Based in the effects caused by these two products, they can be a good alternative for use in peanut crop.

For saflufenacil, among the evaluated cultivars, no significant differences were noticed. Phytotoxicity levels were, in mean values, 3.5 according to EWRC (1964) scale and this is considered a mild intoxication. Symptoms shown by plants were yellowed leaves and burns due to PROTOX inhibition. Morichetti, Ferrell, MacDonald, Sellers, and Rowland (2012) verified similar effects studying doses of saflufenacil on cultivars Georgia Green and Florida 07 at 7 days after treatment (DAT). In this occasion, the authors observed that leaf lesions in peanut crops submitted to saflufenacil application were of 15 to $23 \%$, as the dose was increased from 12 to $50 \mathrm{~g}^{-1}$. However, along the experimental period, it was verified that the effect diminished from 9 to $5 \%$ and there was no difference between the doses. According to these authors, the effect of saflufenacil doses did not affect the yield of the peanut crops at $50 \mathrm{~g} \mathrm{ha}^{-1}$ dose for Amaranthus palmeri species (resistant to ALS and EPSPS herbicides) showing that it was more efficient than lactofen.

Among the other products evaluated, herbicides amicarbazone, hexazinone and tebuthiuron were the only ones that caused the death of all cultivars. Regarding the herbicides tested, these are the only ones that have as action mechanism the inhibition of photosystem II (PSII). Inhibition of PSII occurs after the absorption of the herbicide by the plant. These herbicides act in the chloroplast membrane, causing the reduction of photosynthetic pigments and promoting the inhibition of the luminous phase, causing the reduction of the electron transport (Rodrigues $\&$ Almeida, 2011). In the present study, the cultivars that were most sensible to these herbicides presented chlorotic spots on leaves, followed by foliar necrosis, growth reduction and death. These symptoms indicate that these products caused the reduction in the photosynthetic pigments next to the application (7 DAA), and caused necrosis and posterior death of most genotypes at 21 DAA, except for cultivars IAC 503 and IAC 505 under tebuthiuron treatment, in which even not dying at 21 DAA, presented high levels of phytointoxication and a critical state, without chance of recovery. Considering the inhibition caused in PSII, these herbicides are not selective for peanut crop, and should not be recommended in post-emergence application.

Among the products tested in the present study, imazapic is the only herbicide registered for use in peanut crop and, as it was expected, its phytotoxical effects were weak, except for Line 870 , which showed intermediary level (6.5), showing that the genetic variability exists between cultivars. These data corroborate researches previously made by Ducar et al. (2009), which verified that injuries in peanut did not exceed $3 \%$ when applied $70 \mathrm{~g} \mathrm{ha}^{-1}$ of this product in post emergence. Luvezutti et al. (2014) observed similar effect when applying doses of $140 \mathrm{~g} \mathrm{ha}^{-1}$. However, in many studies, the authors did not observe visible intoxications in peanut plants when tested imazapic with $150 \mathrm{~g} \mathrm{ha}^{-1}$ (Ricchburg III, Wilcut, Colvin, \& Wiley, 1996) and $70 \mathrm{~g} \mathrm{ha}^{-1}$ (Grichar, 1997). Dotray, Baughman, Keeling, Grichar and Lemon (2001) concluded that in peanut, damaging of imazapic in post-emergence is of minor impact and authors mention that the product may be applied in many stages of growth and development without compromising peanut yield.

\section{Conclusion}

Based on the results obtained, it is concluded that the herbicides $2,4-\mathrm{D}\left(1.50 \mathrm{~L} \mathrm{ha}^{-1}\right)$, mesotrione $\left(0.3 \mathrm{~L} \mathrm{ha}^{-1}\right)$, saflufenacil $\left(0.75 \mathrm{~L} \mathrm{ha}^{-1}\right)$, imazapic $\left(175 \mathrm{~g} \mathrm{ha}^{-1}\right)$ and S-metolachlor $\left(1.75 \mathrm{~L} \mathrm{ha}^{-1}\right)$ have potential usage for all the peanut cultivars studied. Herbicides hexazinone $\left(2.50 \mathrm{~kg} \mathrm{ha}^{-1}\right)$, amicarbazone $\left(2.00 \mathrm{~kg} \mathrm{ha}^{-1}\right)$, tebuthiuron $(2.00 \mathrm{~L}$ 
$\left.\mathrm{ha}^{-1}\right)$, clomazone $\left(2.00 \mathrm{~L} \mathrm{ha}^{-1}\right)$ and sulfentrazone $\left(1.20 \mathrm{~L} \mathrm{ha}^{-1}\right)$ must not beindicated, at these doses, for post-emergence spraying in the evaluated cultivars.

The genotypes do not react equally to certain products, therefore, there is a need for further studies at field conditions to attest the responses obtained in the present study and verify that the yield potential is not affected.

\section{References}

Agostinho, F. H., Gravena, R., Alves, P. L. C. A., Salgado, T. P., \& Mattos, E. D. (2006). The effect of cultivar on critical periods of weed control in peanuts. Peanut Science, 33(1), 29-35. https://doi.org/10.3146/0095-3679 (2006)33[29:TEOCOC]2.0.CO;2

Alvino, C., Gricio, L., Sampaio, F., Girotto, M., Felipe, A., Junior, C., \& Lima, F. (2011). Interferência e controle de plantas daninhas nas culturas agrícolas. Revista Científica Eletrônica de Agronomia, 10(1), 1-4. Retrieved from http://faef.revista.inf.br/imagens_arquivos/arquivos_destaque/8PS4j9vvbVATTby_2013-517-17-29-45.pdf

Armel, G. R., Wilson, H. P., Richardson, R. J., \& Hines, T. E. (2003). Mesotrione, Acetochlor, and Atrazine for Weed Management in Corn (Zea mays). Weed Technology, 17(2), 284-290. https://doi.org/10.1614/ 0890-037X(2003)017[0284:MAAAFW]2.0.CO;2

Burke, I. C., Schroeder, M., Thomas, W. E., \& Wilcut, J. W. (2007). Palmer amaranth interference and seed production in peanut. Weed Technology, 21(2), 367-371. https://doi.org/10.1614/WT-06-058.1

CAES (College of Agricultural \& Environmental Sciences). (2003). Commodities: Field Crops. Peanut Pointers. University of Georgia. Retrieved from http://www.caes.uga.edu/extension-outreach/commodities/ peanuts.html

CONAB (Companhia Nacional de Abastecimento). (2017). Safras 1976/77 a 2016/17: Série histórica. Brasília, DF. Retrieved February 2, 2017, from http://www.conab.gov.br/conteudos.php?a=125

CONAB (Companhia Nacional de Abastecimento). (2018). Acompanhamento da Safra Brasileira-Grãos. Retrieved June 4, 2018, from http://www.conab.gov.br

Dotray, P. A., Baughman, T. A., Keeling, J. W., Grichar, W. J., \& Lemon, R. G. (2001). Effect of Imazapic Application Timing on Texas Peanut (Arachis hypogaea). Weed Technology, 15(1), 26-29. https://doi.org/ 10.1614/0890-037X(2001)015[0026:EOIATO]2.0.CO;2.

Ducar, J. T., Clewis, S. B., Wilcut, J. W., Jordan, D. L., Brecke, B. J., Grichar, W. J., \& Wehtje, G. R. (2009). Weed management using reduced rate combinations of diclosulam, flumioxazin, and imazapic in peanut. Weed Technology, 23(2), 236-242. https://doi.org/10.1614/WT-07-180.1

EMBRAPA (Empresa Brasileira de Pesquisa Agropecuária). (2013). Sistema Brasileiro de Classificação de Solos (3rd ed.). Brasília, DF.

EWRC (European Weed Research Council). (1964). Report of the 3rd and 4rd meetings of European Weed Research Council Comittee of Methods in Weed Research. Weedsearch, 4(1), 79. https://doi.org/10.1111/ j.1365-3180.1964.tb00271.x

Farinelli, R., Penariol, F. G., \& Lemos, L. B. (2005). Eficiência do herbicida 2, 4-D no controle de Raphanus raphanistrum L. em pós-emergência na cultura do milheto. Revista Brasileira de Milho e Sorgo, 4(1), 104-111. https://doi.org/10.18512/1980-6477/rbms.v4n1p104-111

Fleck, N. G., Neves, R., Vidal, R. A., \& Vargas, L. (1998). Avaliação de subdoses de herbicidas sistêmicos não-seletivos em soja. Pesquisa Agropecuária Gaúcha, 4(2), 151-156. Retrieved from http://www.fepagro. rs.gov.br/upload/1398911870_art_10.pdf

Grey, T. L., Dotray, P. A., \& Grichar, W. J. (2007). Soil and Residual Herbicide Affect Peanut Seedling Development. Peanut Science, 34(1), 65-70. https://doi.org/10.3146/0095-3679(2007)34[65:SARHAP] 2.0. CO;2

Grichar, W. J. (1997). Control of Palmer amaranth (Amaranthus palmeri) in peanut (Arachis hypogaea) with postemergence herbicides. Weed Technology, 11(4), 739-743. https://doi.org/10.1017/S0890037X00043360

Heap, I. (2017). The International Survey of Herbicide Resistant Weeds. Retrieved February 14, 2017, from http://www.weedscience.org

Leon, R. G., \& Tillman, B. L. (2015). Postemergence herbicide tolerance variation in peanut germplasm. Weed Science, 63(2), 546-554. https://doi.org/10.1614/WS-D-14-00128.1 
Leon, R. G., Ferrell, J. A., \& Brecke, B. J. (2014). Impact of exposure to 2,4-D and dicamba on peanut injury and yield. Weed Technology, 28(3), 465-470. https://doi.org/10.1614/WT-D-13-00187.1

Luvezuti, R. A., Bacha, A. L., Alves, P. L. C. A., Pavani, M. C. M. D., \& Nepomuceno, M. P. (2014). Eficácia de herbicidas no controle de plantas daninhas e seletividade na cultura do amendoim Runner IAC 886. Revista Brasileira de Herbicidas, 13(3), 207-215. https://doi.org/10.7824/rbh.v13i3.290

MAPA (Ministério da Agricultura, Pecuária e Abastecimento). (2017). Cultura com Suporte Fitossanitário Insuficiente. Registro de agrotóxicos para culturas com suporte fitossanitário insuficiente. Manual de procedimentos (Instrução Normativa Conjunta 01, p. 24). Retrieved June 6, 2017, from $\mathrm{http} / /$ www.agricultura.gov.br/assuntos/insumos-agropecuarios/insumos-agricolas/agrotoxicos/culturas-com -suporte-fitossanitario-insuficiente-csfi

Martins, D., Triguero, L. R. C., Domingos, V. D., Martins, C. C., Marchi, S. R. D., \& Costa, N. V. D. (2007). Seletividade de herbicidas aplicados em pós-emergência sobre capim-braquiária. Revista Brasileira de Zootecnia, 36(6), 1969-1974. https://doi.org/10.1590/S1516-35982007000900004

Morichetti, S., Ferrell, J., MacDonald, G., Sellers, B., \& Rowland, D. (2012). Weed management and peanut response from applications of saflufenacil. Weed Technology, 26(2), 261-266. https://doi.org/10.1614/ WT-D-11-00095.1

Nepomuceno, M. P., Alves, P. L. C. A., Dias, T. C. S., Cardozo, N. P., \& Pavani, M. C. M. D. (2007). Efeito da época de semeadura nas relações de interferência entre uma comunidade infestante e a cultura do amendoim. Planta Daninha, 25(3), 481-488. https://doi.org/10.1590/S0100-83582007000300007

Oliveira Jr., R. S., \& Inoue, M. H. (2011). Seletividade de Herbicidas para Culturas e Plantas Daninhas. In R. S. Oliveira Jr., \& J. C. e M. H. Inoue (Eds.), Biologia e Manejo de Plantas Daninhas (1st ed.). Curitiba, PR.

Pitelli, R. A. (1985). Interferência de plantas daninhas em culturas agrícolas. Informe Agropecuário, 11, 16-27.

Prostko, E. P., Webster, T. M., Marshall, M. W., Leon, R. G., Grey, T. L., Ferrell, J. A., \& Brecke, B. J. (2013). Glufosinate application timing and rate affect peanut yield. Peanut Science, 40(2), 115-119. https://doi.org/10.3146/PS13-4.1

Rodrigues, B. N., \& Almeida, F. S. (2011). Guia de herbicidas (6th ed.). Londrina, PR.

Santos, R. C., Freire, R. M. M., \& Lima, L. M. (2013). O agronegócio do amendoim no Brasil (2nd ed.). Brasília, DF.

Thomas, W. E., Troxler, S. C., Smith, W. D., Fisher, L. R., \& Wilcut, J. W. (2005). Uptake, translocation, and metabolism of sulfentrazone in peanut, prickly sida (Sida spinosa), and pitted morningglory (Ipomoea lacunosa). Weed Science, 53(4), 446-450. https://doi.org/10.1614/WS-04-085R2

USDA (United States Departamento of Agriculture). (2018). World Agricultural Production. Circular Series WAP 01-17. Foreign Agricultural Service. Retrieved June 4, 2018, from https://apps.fas.usda.gov/psdonline/ circulars/production.pdf

Yamauti, M. S., Alves, P. L. C. A., Nepomuceno, M., \& Martins, J. V. F. (2010). Adubação e o período anterior à interferência das plantas daninhas na cultura do amendoim. Planta Daninha, 28, 1031-1039. https://doi.org/ $10.1590 / \mathrm{S} 0100-83582010000500011$

\section{Copyrights}

Copyright for this article is retained by the author (s), with first publication rights granted to the journal.

This is an open-access article distributed under the terms and conditions of the Creative Commons Attribution license (http://creativecommons.org/licenses/by/4.0/). 